\title{
Seasonal Patterns of Root Production with Water and Nitrogen Additions Across Three Dryland Ecosystems
}

\author{
Jessica G. Swindon, Ingrid C. Burke, ${ }^{*}$ and William K. Lauenroth
}

Yale School of Forestry and Environmental Studies, 195 Prospect St., New Haven, Connecticut 06511, USA

\begin{abstract}
Root production is known to contribute at least $50 \%$ of total net primary production in dryland ecosystems, yet few studies have addressed seasonal dynamics of root production or the belowground response to altered resource availability. We aimed to identify how root production varies across three dryland ecosystems dominated by different plant functional types: the shortgrass steppe, dominated by $\mathrm{C}_{4}$ perennial bunchgrasses, the northern mixed-grass prairie, co-dominated by perennial $\mathrm{C}_{3}$ and $\mathrm{C}_{4}$ grasses, and the sagebrush steppe, dominated by a perennial shrub with an understory of $\mathrm{C}_{3}$ and $\mathrm{C}_{4}$ grasses and forbs. We also sought to determine how root production changes throughout a growing season for these three systems, and how it responds to increased water and nitrogen availability. We used root ingrowth cores to monitor root production in 6-week intervals between June 1 and October 5, 2017, and with water and nitrogen additions in shortgrass steppe,
\end{abstract}

mixed-grass prairie, and sagebrush steppe in the western Great Plains of the United States. We found that the northern mixed-grass prairie had the highest total root production during our sampling period, and that seasonal patterns of root growth varied significantly across the dryland types, with root growth greatest during the middle of the growing season at the sagebrush steppe and greatest during the end of the growing season at the northern mixed-grass prairie. As expected, belowground root production was about half aboveground production in all sites. Root production responded less to water and nitrogen addition than did aboveground production.

Key words: drylands; root production; belowground production; shortgrass steppe; northern mixed-grass prairie; sagebrush steppe; water and nitrogen additions.

\section{HighLIGHTS}

Received 6 December 2018; accepted 10 February 2019; published online 8 April 2019

Electronic supplementary material: The online version of this article (https://doi.org/10.1007/s10021-019-00364-y) contains supplementary material, which is available to authorized users.

Authors Contributions JGS conceived study, performed research, analyzed data, and wrote paper. ICB co-conceived study and co-wrote paper. WKL co-conceived study, contributed methods, and co-wrote paper.

*Corresponding author; e-mail: indy.burke@yale.edu

- Root production varies through the growing season and across dryland ecosystem types;

- Root production in three types of drylands is about half total production; and

- Root production responded less to water and nitrogen than did aboveground production. 


\section{INTRODUCTION}

Over the next century, shifting climate regimes leading to unknown changes in water and nitrogen (hereafter $\mathrm{N}$ ) availability are expected to affect dryland structure and function in the US Great Plains (Huang and others 2016; Palmquist and others 2016). Predicting how dryland ecosystems will respond to changes in resource availability is particularly important because they cover approximately $40 \%$ of the Earth's terrestrial surface and contain substantial stores of soil carbon (Batjes 1996; White and others 2000). Changes in water and $\mathrm{N}$ availability are known to influence vegetation dynamics and aboveground net primary production (Lauenroth and others 1978; Fay and others 2003; Yahdjian and others 2011; Stevens and others 2015), altering important ecosystem processes that are linked to the carbon cycle (Wedin and Tilman 1996). In dryland ecosystems, belowground net primary production often contributes greater than $50 \%$ of total net primary production (Sims and others 1978; Milchunas and Lauenroth 2001) and at least $75 \%$ of plant biomass is belowground (Burke and others 1997a), yet relatively few studies have investigated seasonal dynamics of root production, or the belowground response to altered water and/or $\mathrm{N}$ availability in drylands (Peng and others 2017).

Several meta-analyses have been conducted to assess global patterns in root turnover (Jackson and others 1997; Gill and Jackson 2000). These studies indicate that temperate grasslands have the highest fine root biomass per unit area of any ecosystem in the world and among the highest fine root turnover rates and that spatial patterns in root turnover are strongly influenced by mean annual temperature, while interannual temporal patterns in single grassland are strongly correlated with annual precipitation. In a study of phenology of roots compared with shoots for monoculture-grown shrubs and grasses in Canada (Steinaker and others 2010), researchers found that root production was in general most closely related to soil temperature. Despite the importance of seasonal and pulse-oriented controls over ecosystem processes in drylands (for example, Austin and others 2004), we know very little about the seasonal dynamics of root production-the key carbon input-for drylands (Gill and others 2002).

Together water and $\mathrm{N}$ are the most frequent limiting resources for net primary production in drylands (Lauenroth and others 1978; Hooper and Johnson 1999). Regional analyses and field experiments have linked aboveground net primary pro- duction to mean annual precipitation (water availability) and $\mathrm{N}$ availability (Lauenroth 1979; Sala and others 1988; Milchunas and Lauenroth 1993; Epstein and others 1998b) and have revealed that with increasing mean annual precipitation, the frequency of water limitation decreases, while the frequency of $\mathrm{N}$ limitation increases (Yahdjian and others 2011). Net primary production is highly variable across spatial and temporal scales and depends largely on climate patterns and soil characteristics that determine important ecosystem processes including soil water residence time and $\mathrm{N}$ mobility (Power and Alessi 1971; Sala and others 1992; Austin and others 2004). An analysis of aboveground net primary production patterns in the central grassland region of the United States revealed that regional scale differences can be explained by mean annual precipitation, while most of the within-site variability could be explained by annual precipitation, soil water holding capacity, and their interaction (Sala and others 1988; Lauenroth and Sala 1992). However, there is a high degree of spatial and temporal covariance between water and $\mathrm{N}$ availability (Burke and others 1997b). Interannual variability is high in aboveground and belowground net primary production (Power and Alessi 1971; Hayes and Seastedt 1987; Liu and Greaver 2010) and can often be as large as a twofold difference. The magnitude of ecosystem response to altered resource availability both regionally and annually is highly site specific (Sala and others 1988; McCulley and others 2005).

Understanding how plant functional types respond to changes in resource availability is an important component of predicting large-scale shifts in ecosystem structure and function (Epstein and others 1997). Grasses and shrubs are the most frequent dominant plant functional types in dryland ecosystems and have different spatial root patterns that determine their ability to acquire belowground resources (Walter 1971; Sala and others 1989; Lee and Lauenroth 1994). Grasses acquire the majority of their water and nutrients from upper soil layers and typically have a higher concentration of $\mathrm{N}$ in aboveground biomass, and a lower $\mathrm{N}$ residence time than shrubs, which may partially explain why grasses and shrubs respond differently to increased water and $\mathrm{N}$ additions (Sala and others 2012; Yahdjian and others 2014). Coolseason $\left(C_{3}\right)$ and warm-season $\left(C_{4}\right)$ grasses tend to have distinctive dynamics in resource use and uptake, as well (Epstein and others 1998a).

We sought to examine how water and $\mathrm{N}$ additions affect belowground net primary production (root production) throughout a growing season and 
across three dryland ecosystem types in the western Great Plains of the USA; each ecosystem type is dominated by a different plant functional type. The questions that guided our research are:

1. How does root production vary across three dryland ecosystem types in the Great Plains of North America?

2. What are the intra-seasonal dynamics of root production and do they differ among three ecosystem types?

3. How does increased water and $\mathrm{N}$ availability affect the intra-seasonal dynamics of root production in our three ecosystem types?

\section{Methods}

\section{Site Description}

We conducted this study within three semiarid ecosystem types in the western Great Plains of the United States: the shortgrass steppe, the northern mixed-grass prairie, and the sagebrush steppe. We chose a representative site within each ecosystem type and set up three replicate plots at each site. All three sites were located on level uplands, have a history of moderate cattle grazing during the growing season, and are currently managed for this purpose. We excluded livestock during the experiment using fenced exclosures.

The Central Plains Experimental Range (CPER) in the shortgrass steppe is located $61 \mathrm{~km}$ northeast of Fort Collins, Colorado $\left(40^{\circ} 49^{\prime} \mathrm{N}, 104^{\circ} 43^{\prime} \mathrm{W}\right)$, at an average elevation of $1650 \mathrm{~m}$. CPER is overseen by the United States Department of Agriculture's (USDA) Agricultural Research Service (ARS) and was formerly a National Science Foundation LongTerm Ecological Research site (Lauenroth and Burke 2008). Mean annual temperature is $8.7^{\circ} \mathrm{C}$ and mean monthly temperatures range from $9.8^{\circ} \mathrm{C}$ in December to $30.7^{\circ} \mathrm{C}$ in July (Figure 1A). Mean annual precipitation is $341 \mathrm{~mm}$ (PRISM Climate Group 2018) and approximately $75 \%$ of the annual precipitation falls between April and September (Pielke and Doesken 2008). The plant community is dominated by the short-statured $\mathrm{C}_{4}$ perennial bunchgrasses blue grama (Bouteloua gracilis) and buffalo grass (Bouteloua dactyloides). The subshrub prairie sagewort (Artemisia frigida) and plains pricklypear (Opuntia polyacantha) are present across the landscape, and bare ground patches are common (Lauenroth 2008) (nomenclature follows USDA, NRCS 2018).

The northern mixed-grass prairie site is located in the High Plains Grasslands Research Station
(HPGRS) and overseen by the USDA-ARS. The site is located $7 \mathrm{~km}$ northwest of Cheyenne, Wyoming $\left(41^{\circ} 12^{\prime} \mathrm{N}, 104^{\circ} 54^{\prime} \mathrm{W}\right)$, and has an average elevation of $1930 \mathrm{~m}$. Mean annual temperature is $7.4^{\circ} \mathrm{C}$ and mean monthly temperatures range from $-8.8^{\circ} \mathrm{C}$ in December to $27.9^{\circ} \mathrm{C}$ in July (Figure 1B). Mean annual precipitation is $393 \mathrm{~mm}$ (PRISM Climate Group 2018). The vegetation at HPGRS is composed of a mixture of $\mathrm{C}_{3}$ and $\mathrm{C}_{4}$ perennial grass species including western wheatgrass (Pascopyrum smithii), needle and thread (Hesperostipa comata), and $B$. gracilis. $\mathrm{C}_{3}$ forbs and the subshrub, prairie sagewort (Artemisia frigida) are also common across the landscape (Derner and others 2008).

The sagebrush steppe site is within the boundaries of the Thunder Basin National Grassland (TBNG). Our site was located on an inholding owned by The Nature Conservancy. The site is located $64 \mathrm{~km}$ northeast of Douglas, Wyoming $\left(43^{\circ} 25^{\prime} \mathrm{N}, 104^{\circ} 56^{\prime} \mathrm{W}\right)$, and has an average elevation of $1500 \mathrm{~m}$. Mean annual temperature is $8.1^{\circ} \mathrm{C}$ and mean monthly temperatures range from $-11.1^{\circ} \mathrm{C}$ in December to $31.7^{\circ} \mathrm{C}$ in July. Mean annual precipitation is $331 \mathrm{~mm}$ (Figure 1C) (PRISM Climate Group 2018). Big sagebrush (Artemisia tridentata) is the dominant shrub and the understory is a mixture of $\mathrm{C}_{3}$ and $\mathrm{C}_{4}$ grasses and forbs, including $B$. gracilis, $H$. comata, and $P$. smithii (Pennington and others 2019) and plains pricklypear (Opuntia polyacantha).

\section{Experimental Treatments}

Each site consisted of three exclosures $(14.5 \mathrm{~m} \times 14.5 \mathrm{~m})$ that were equally spaced across the landscape. The vegetation within the exclosures had similar plant community structure, ground cover, and sandy loam or loam soils (Swindon and others 2019). Within each exclosure, we established four subplots $(3 \mathrm{~m} \times 3 \mathrm{~m})$ separated by a $6 \mathrm{~m}$ buffer. Each subplot was randomly assigned a treatment: control, water, $\mathrm{N}$, or water plus $\mathrm{N}$. We dissolved $\mathrm{N}$ in the form of urea $\left(\mathrm{CH}_{4} \mathrm{~N}_{2} \mathrm{O}\right)$ with water and applied it one time between June 1 and 32017 , at $100 \mathrm{~kg} \mathrm{~N} / \mathrm{ha}$, about 5 10 times the annual flux of net $\mathrm{N}$ mineralization (Burke and others 2008; Korfanta and others 2015). For the water and water plus $\mathrm{N}$ treatments, we increased the average monthly precipitation for each site by $40 \%$ based on NOAA's Climate Normals (Arguez and others 2010) from the nearest climate station to ensure that a "higher than average" amount of water was added to the treatments (Online Appendix 1); the plots received $76 \mathrm{~mm}$ (shortgrass steppe), $82 \mathrm{~mm}$ (northern 

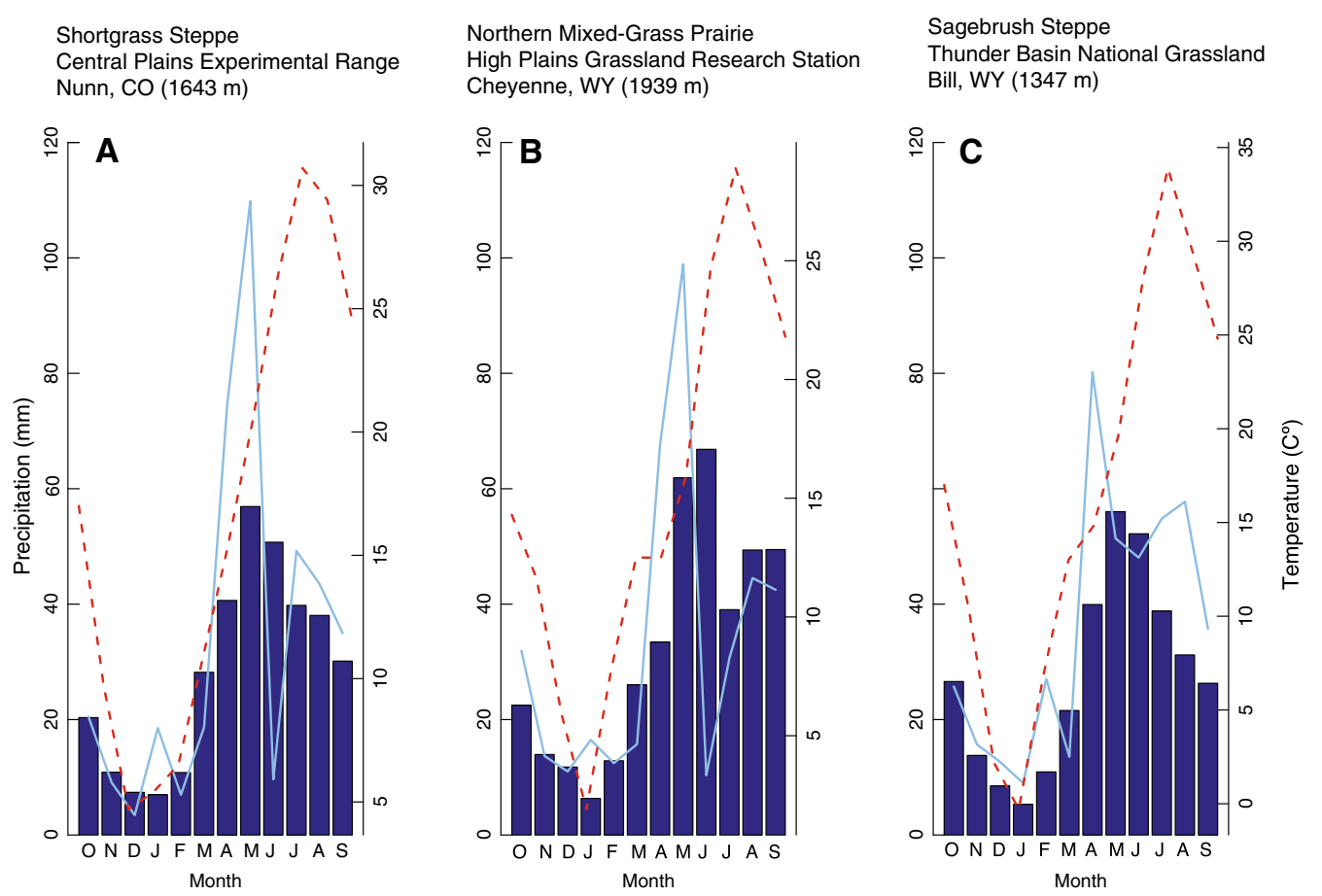

Figure 1. Climate data for the shortgrass steppe, northern mixed-grass prairie, and sagebrush steppe sites. The bars represent long-term monthly precipitation averages (1981-2010) generated from PRISM (PRISM Climate Group 2018). The light-blue line is the monthly precipitation from October 2016 to September 2017 and the red dotted line is the average monthly temperature from October 2016 to September 2017.

mixed-grass prairie), and $56 \mathrm{~mm}$ (sagebrush steppe). The subplots received water application once at the beginning of each month starting on the first week of June 2017 and ending in the first week of September 2017.

\section{Field Measurements: Belowground Net Primary Production and Aboveground Production}

To estimate root production, we used the root ingrowth method (Vogt and others 1998; McCulley and others 2005; Byrne and others 2013). We created $5 \mathrm{~cm}$ diameter ingrowth screens that were $20 \mathrm{~cm}$ long using 2-mm-fiberglass mesh screen, which allows for fine root growth (Montagnoli and others 2014). We produced a total of 756 ingrowth screens and placed 21 ingrowth cores per treatment per exclosure at each site, for a total of 63 cores per treatment per site. To place each ingrowth core into the ground, we used a $5 \mathrm{~cm}$ diameter hole saw attached to a hand drill and drilled to a depth of $20 \mathrm{~cm}$. We placed the ingrowth cores in the first week of June, systematically and equally spaced within each subplot to equalize disturbance to each core from the placement of nearby cores. At each plot, we combined the extracted soil and sieved it twice with a 5-mm screen to remove live and dead root biomass. We placed the ingrowth screens into the holes and filled them with the root-free soil. To account for bulk density at each site, we used a field scale to measure the mass of soil per core and compressed the soil manually (Van Haveren and Galbraith 1971; Abdel-Magid and others 1987; Gasch and others 2016). To estimate intra-seasonal root production, we extracted a random set of onethird of the cores every 6 weeks starting on July 14, with the final set extracted at week eighteen on October 5, with the overall time period designed to match the period that has been shown to capture the majority of seasonal root growth (Hayes and Seastedt 1987; Sindhoj and others 2000).

To understand how treatments may have impacted aboveground net primary production, we sampled aboveground biomass at the end of the growing season between October 1 and 8 as an estimate of production (Lauenroth and others 1986); we chose these dates to correspond with the last root production estimate, and because comparisons across sites for the aboveground production were not a key question for this study. We randomly placed five $20 \times 50 \mathrm{~cm}$ quadrats inside each treatment subplot and clipped the aboveground biomass of all species except woody shrubs 
such as Artemisia tridentata, because of the difficulty of estimating current year's growth. We separated the aboveground biomass into grasses and forbs, cacti, and Artemisia frigida, because they represented the important plant functional types. We chose to exclude cacti from this analysis, because our quadrats were too small to obtain a useful biomass estimate. We air-dried the samples for at least $72 \mathrm{~h}$ and converted aboveground biomass to grams per meter squared $\left(\mathrm{g} \mathrm{m}^{-2}\right)$. Our estimate of aboveground production is likely an underestimate because of dried leaves that may have blown away after they senesced and before we sampled, and because we did not include an estimate of aboveground production for woody shrubs. The underestimate was probably largest for the sagebrush site, for this reason; still the method we used should capture treatment effects on all grasses, forbs, and the subshrub Artemisia frigida.

\section{Laboratory Analysis}

We air-dried the root ingrowth cores for $72 \mathrm{~h}$ and washed the soil from the belowground biomass using the methods of Lauenroth and Whitman (1971). We dried the biomass at $55^{\circ} \mathrm{C}$ for $48 \mathrm{~h}$, separated the roots from the remaining organic material by hand, and weighed the roots. To eliminate contamination of residual soil particles, we ashed the samples in a muffle furnace at $450^{\circ} \mathrm{C}$ for $4 \mathrm{~h}$ (Harmon and others 1999). We used the ash-free dry weight to calculate grams of dry biomass per meter squared $\left(\mathrm{g} \mathrm{m}^{-2}\right)$.

\section{Data Analysis}

Our experiment used a split-plot design; the water and $\mathrm{N}$ treatments were the subplot level, and time was the sub-subplot level. This design allowed us to calculate error terms for each level that resulted from the experimental design, assuming that different treatments were assigned randomly to sampling units at different scales. We used the diagwl function within the agricolae package in $\mathrm{R}$ (R Core Team 2018) to conduct the split-plot analysis and tested for the effect of site, treatment, time, and their interaction on root production, for each of our three study questions. We then conducted least squares mean separation tests to identify which means were statistically different from each other. To test for treatment effects on aboveground production of grasses, forbs, and A. frigida, we used a one-way analysis of variance followed by Tukey's HSD for each site.

To evaluate the seasonal dynamics, we conducted two analyses. First, we compared the incremental values (total biomass in cores per site per treatment per time frame) for $0-6,0-12$, and 0 18 weeks, to determine whether there was a significant difference among time frames; if not, it means that no production occurred during the subsequent time frame. Next, we calculated the difference between time frames to estimate production for the 6-12 and 12-18 week periods. We did this by subtracting the mean production of 0 6 weeks from 0 to 12 weeks and subtracting the mean production of 6-12 weeks from 0 to 18 weeks.

\section{RESUlTS}

\section{Temperature and Precipitation}

Across the three sites, mean annual temperature in 2016-2017 was consistent with long-term averages, deviating no more than $0.5^{\circ} \mathrm{C}$ from the annual average. Throughout the experiment, both the total amount and seasonal distribution of growing season precipitation varied substantially from long-term climate normals (PRISM Climate Group 2018) (Figure 1). Water-year precipitation from October 2016 through September 2017 was higher than the long-term averages (PRISM Climate Group 2018) at all our sites. At the shortgrass steppe site, the highest percentage of precipitation fell in the early growing season months of April and May 2017 and was followed by an unusually dry June, receiving only $10 \mathrm{~mm}$ of precipitation as compared to the long-term average of $51 \mathrm{~mm}$ (Figure 1A). Long-term mean water-year precipitation is $367 \mathrm{~mm}$ at the northern mixed-grass prairie site and during our study, the site received approximately $372 \mathrm{~mm}$ (Figure 1B). April and May 2017 received on average $30 \mathrm{~mm}$ more precipitation than the long-term average and this site also experienced an unusually dry June (a difference of $57 \mathrm{~mm}$ from the long-term average). At the sagebrush steppe, the long-term water-year precipitation is $396 \mathrm{~mm}$ and the site received $331 \mathrm{~mm}$ in 2016-2017, a difference of $65 \mathrm{~mm}$ (Figure 1C). Mean precipitation in August 2017 was particularly high for this site, receiving $27 \mathrm{~mm}$ more precipitation than the long-term average.

\section{Root Production Across Ecosystem Types and Through Time}

Root production of the control plots after 18 weeks was not significantly different between the shortgrass steppe site $\left(92 \mathrm{~g} \mathrm{~m}^{-2}\right)$ and northern mixedgrass prairie site $\left(113 \mathrm{~g} \mathrm{~m}^{-2}\right)$, but was significantly 
lower at the sagebrush steppe site $\left(32 \mathrm{~g} \mathrm{~m}^{-2}\right)$ than the other two sites (Table 1, Figure 2). At the shortgrass steppe site, the rate of root production was relatively constant throughout the growing season across all treatments. The rate of root production at the northern mixed-grass prairie site increased with time during the growing season, corresponding with patterns of precipitation (Figure $1 \mathrm{~B}$ ), with the highest production in the final 6week period. This trend was consistent across all treatments except the $\mathrm{N}$ treatment. At the sagebrush steppe, root production peaked during the second 6-week interval across all treatments; between the second and third 6-week interval, there was no additional root production for the control, $\mathrm{N}$, and water treatments.

\section{Root Production Across Treatments}

Root production was highly variable at all sites throughout the season (Table 1). As a consequence, though we found a trend of increased root production with water and water plus $\mathrm{N}$ additions for all sites, there were few statistically significant differences. Both the shortgrass steppe and the mixed-grass prairie demonstrated trends of higher root production in both water treatments during the $0-6,0-12$, and $0-18$ week intervals than the control or $\mathrm{N}$ treatments. At the northern mixedgrass prairie site, there was significantly higher production in the water plus $\mathrm{N}$ treatment than in the $\mathrm{N}$ treatment (Figure $2 \mathrm{~B}$ ).

\section{Aboveground Production Across Ecosystem Types and by Treatment}

Similar to root production, the combined aboveground biomass of the dominant plant functional types, grasses, forbs, and A. frigida of the control plots was significantly lower at the sagebrush steppe site $\left(67 \mathrm{~g} \mathrm{~m}^{-2}\right)$ than at the shortgrass steppe $\left(105 \mathrm{~g} \mathrm{~m}^{-2}\right)$ or the northern mixed-grass prairie sites $\left(107 \mathrm{~g} \mathrm{~m}^{-2}\right)$ (Figure 3). Aboveground biomass in the water plus $\mathrm{N}$ treatment was higher than any of the other treatments at all three sites, but the difference was only significant at the northern mixed-grass prairie and sagebrush steppe sites.

\section{Discussion}

Across the three ecosystem types, root production and aboveground production were highest at the northern mixed-grass prairie site and lowest at the sagebrush steppe site, following the trends in annual precipitation. Seasonal trends in root pro- duction also matched precipitation at each site. The rate of root production was approximately constant throughout the growing season at the shortgrass steppe site, greatest during the end of the growing season at the northern mixed-grass prairie, and greatest during the middle of the growing season at the sagebrush steppe; all of these trends match the seasonal trends in precipitation. Finally, additions of water, but not nitrogen (alone), led to trends of higher aboveground and belowground production.

\section{Root Production Across Ecosystem Types}

Root production over the growing season (JuneSeptember) was significantly higher at the shortgrass steppe and the northern mixed-grass prairie sites than at the sagebrush steppe site, following patterns in annual precipitation. Although Gill and Jackson (2000) and Steinaker and others (2010) suggested that root turnover increases with temperature, these three sites did not vary significantly from one another with respect to temperature. Aboveground biomass of grasses and forbs was also lowest at the sagebrush steppe and consistent with our estimates of root production. Grasses and forbs are shallow-rooted, with approximately $75 \%$ of their total root biomass in the top $20 \mathrm{~cm}$ of soil (Leetham and Milchunas 1985), while shrubs typically have deeper root systems to access deep water stores (Walter 1971). The sagebrush steppe is dominated by the shrub, Artemisia tridentata, and the understory consists of $\mathrm{C}_{3}$ and $\mathrm{C}_{4}$ grasses, forbs, and cacti. Bare ground can be as high as $40 \%$ of ground cover (Pennington and others 2019) as compared to the northern mixed-grass prairie with an average of $7 \%$ (Derner and others 2008) and approximately $20-40 \%$ at the shortgrass steppe (Hook and others 1994). Lower precipitation, lower aboveground biomass, shrubs with deeper roots dominating over grasses, and a high percentage of bare ground at the sagebrush steppe are the most likely explanations for why we found significantly lower root production at the site. We only sampled to $20 \mathrm{~cm}$ depth and therefore, we were most likely to capture root growth from shallow-rooted species, limiting our ability to assess if this trend is consistent for deep-rooted plant functional types.

The Central Plains Experimental Range has been a focus for research into belowground net primary production (Milchunas and Lauenroth 2001; McCulley and others 2005; Milchunas and others 2005; Milchunas 2009). Estimates have been made by a wide variety of methods and range from 65 to 
$1107 \mathrm{~g} \mathrm{~m}^{-2} \mathrm{y}^{-1}$ (Milchunas 2009). McCulley and others (2005) estimated root production for 2 years from May to October using the ingrowth method and reported approximately $200 \mathrm{~g} \mathrm{~m}^{-2} \mathrm{y}^{-1}$ in each year. Milchunas and others (2005) used a variant of the ingrowth method over 4 years and reported an average root production of $93 \mathrm{~g} \mathrm{~m}^{-2} \mathrm{y}^{-1}$ and a range of 52 to $113 \mathrm{~g} \mathrm{~m}^{-2} \mathrm{y}^{-1}$. Our estimate of $93 \mathrm{~g} \mathrm{~m}^{-2} \mathrm{y}^{-1}$ for the control treatment is comparable to these other root ingrowth methods, but low relative to minirhizotron, pulse-isotope dilution, or turnover methods (Milchunas 2009). The difference between our result and that of McCulley and others (2005) suggests that the month of May is an important time for root growth in the shortgrass steppe.

\section{Root Production Through the Growing Season}

Seasonal patterns in root production varied significantly across the three ecosystem types. The rate of root production at the shortgrass steppe site was nearly constant for all treatments throughout the growing season. The site is dominated by the $\mathrm{C}_{4}$ perennial grass Bouteloua gracilis, a species that is well adapted to warm and dry environments and covers approximately $90 \%$ of the surface (Milchunas and others 1989). B. gracilis allocates $75 \%$ or more of its total biomass belowground and extends roots horizontally below the soil surface to access quickly evaporating water stores that are a result of frequent, small rainfall events $(<5 \mathrm{~mm})$ that occur throughout the growing season (Sala and Lauenroth 1985; Hook and Lauenroth 1994). The rate of root production was greatest during the late part of the growing season for all treatments at the northern mixed-grass prairie site (August 24-October 5). The northern mixed-grass prairie is a mixture of $\mathrm{C}_{3}$ and $\mathrm{C}_{4}$ species; $\mathrm{C}_{3}$ grasses are most active aboveground when the average temperatures are cool, and $\mathrm{C}_{4}$ grasses are most active aboveground when temperatures are warm (Epstein and others 1997). Our results suggest that $C_{3}$ root production increased between late August and October, likely because temperatures began to cool and the $\mathrm{C}_{3}$ species increased their photosynthetic activity, and possibly because it had been very dry earlier in the growing season. Our study began on June 1, which may have missed the early growing period for $\mathrm{C}_{3}$ grasses, explaining why we did not see the same trend in the early part of the growing season (June 1-July 14). Our results did not correspond with those of Steinaker and others (2010), who found that in monocultures at a single site in 

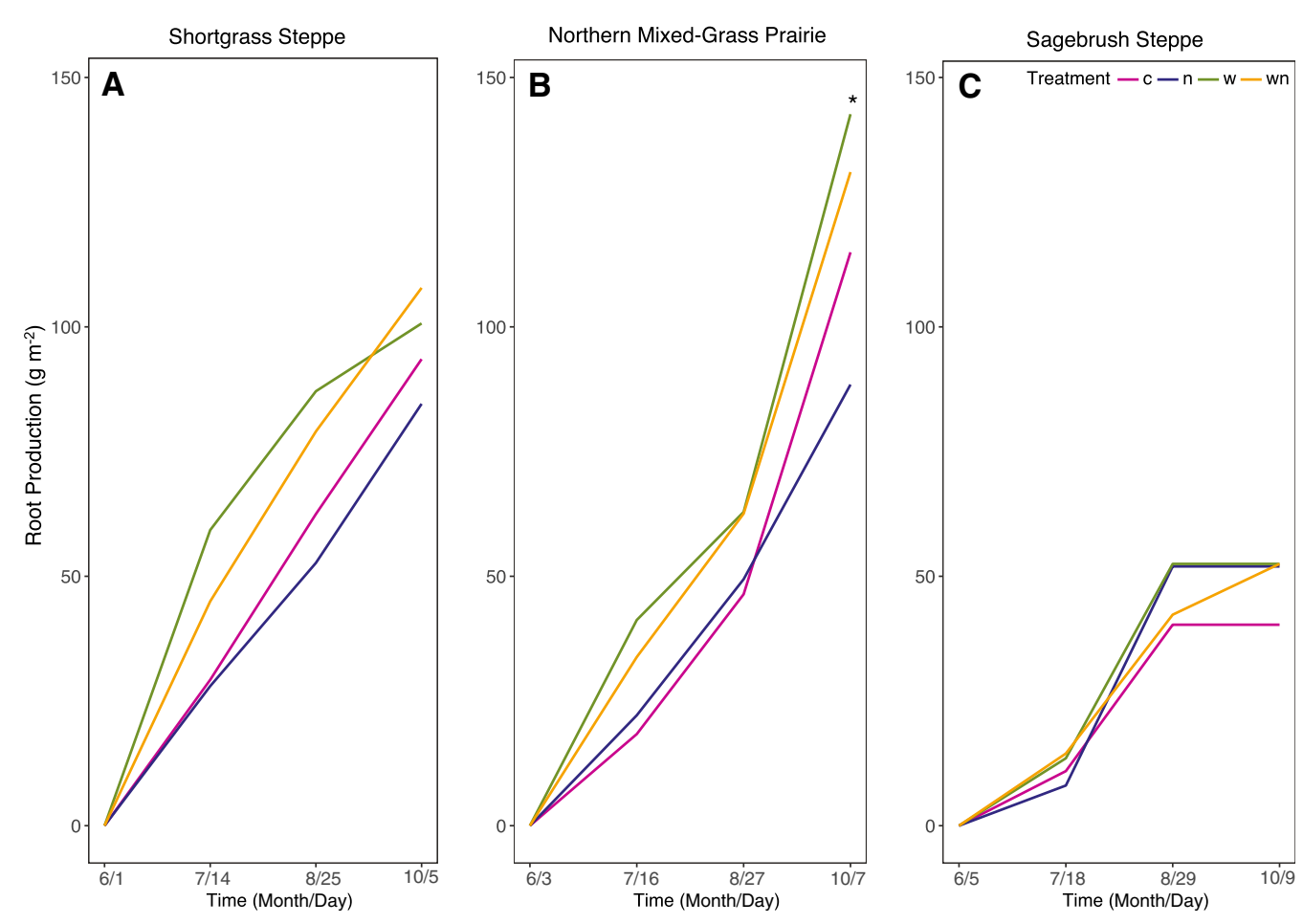

Figure 2. Root production throughout 18 weeks across sites representing three dryland ecosystem types-the shortgrass steppe $(\mathbf{A})$, the northern mixed-grass prairie $(\mathbf{B})$ and the sagebrush steppe $(\mathbf{C})$. All sites received the same treatment regime and each line represents a treatment: control (c), nitrogen (n), water (w), and water plus nitrogen (wn). Significant differences in root production across treatments within sites are labeled with an asterisk $\left.{ }^{*}\right)$.

Canada that $\mathrm{C}_{3}$ species stopped producing by September, whereas the $\mathrm{C}_{4}$ species Bouteloua gracilis increased root production late in the summer. We could not assess whether their finding of a lag in roots behind aboveground production occurred, because we only sampled aboveground production at the end of the season.

In our study, the rate of root production was greatest during the middle of the growing season (July 14 to August 24) for all treatments at the sagebrush steppe site, likely because there was above average rainfall during this time (Figure 1). Typically, the sagebrush steppe experiences dry conditions in July and August; however, in the 2016-2017 growing season, the sagebrush steppe site received $16 \mathrm{~mm}$ more precipitation in July than the average year and $27 \mathrm{~mm}$ more in August, which may have been enough for an increase in water to allow for root production. In the late part of the growing season at the sagebrush steppe, no additional root production occurred in the control, water, and $\mathrm{N}$ treatment, whereas the water and $\mathrm{N}$ treatment still had root growth. This may suggest that environmental conditions were too hot and dry for any additional root production to occur except in the water and $\mathrm{N}$ treatment.

\section{Effects of Water and $\mathrm{N}$ on Root Production}

There have recently been a number of review papers synthesizing the effects of water and $\mathrm{N}$ on root growth, but they vary substantially in their conclusions. In a global analysis of root production along natural gradients in $\mathrm{N}$ and $\mathrm{P}$, Yuan and Chen (2012) found that fine root production increases with $\mathrm{N}$ and conclude that increases in $\mathrm{N}$ availability globally are likely to result in higher fine root production. Peng and others (2017) and Peng and Yang (2016), however, evaluated data sets of experimental manipulations of $\mathrm{N}$ and the resulting impacts on root production and root/shoot ratios under $\mathrm{N}$ enrichment and found an overall pattern of decreasing root/shoot ratio with $\mathrm{N}$ addition for grasslands as well as forests, wetlands, and tundra. There is a very high variability in the data they report for ecosystems with less than $1000 \mathrm{~mm}$ annual precipitation. Finally, other authors ( $\mathrm{Li}$ and others 2011; Gao and others 2011) found in water and $\mathrm{N}$ addition experiments in Inner Mongolia that root production increased under water additions and decreased under $\mathrm{N}$ additions. Baer and Blair (2008) found no root biomass response to enriched $\mathrm{N}$ in a long-term study, but Fornara and others 

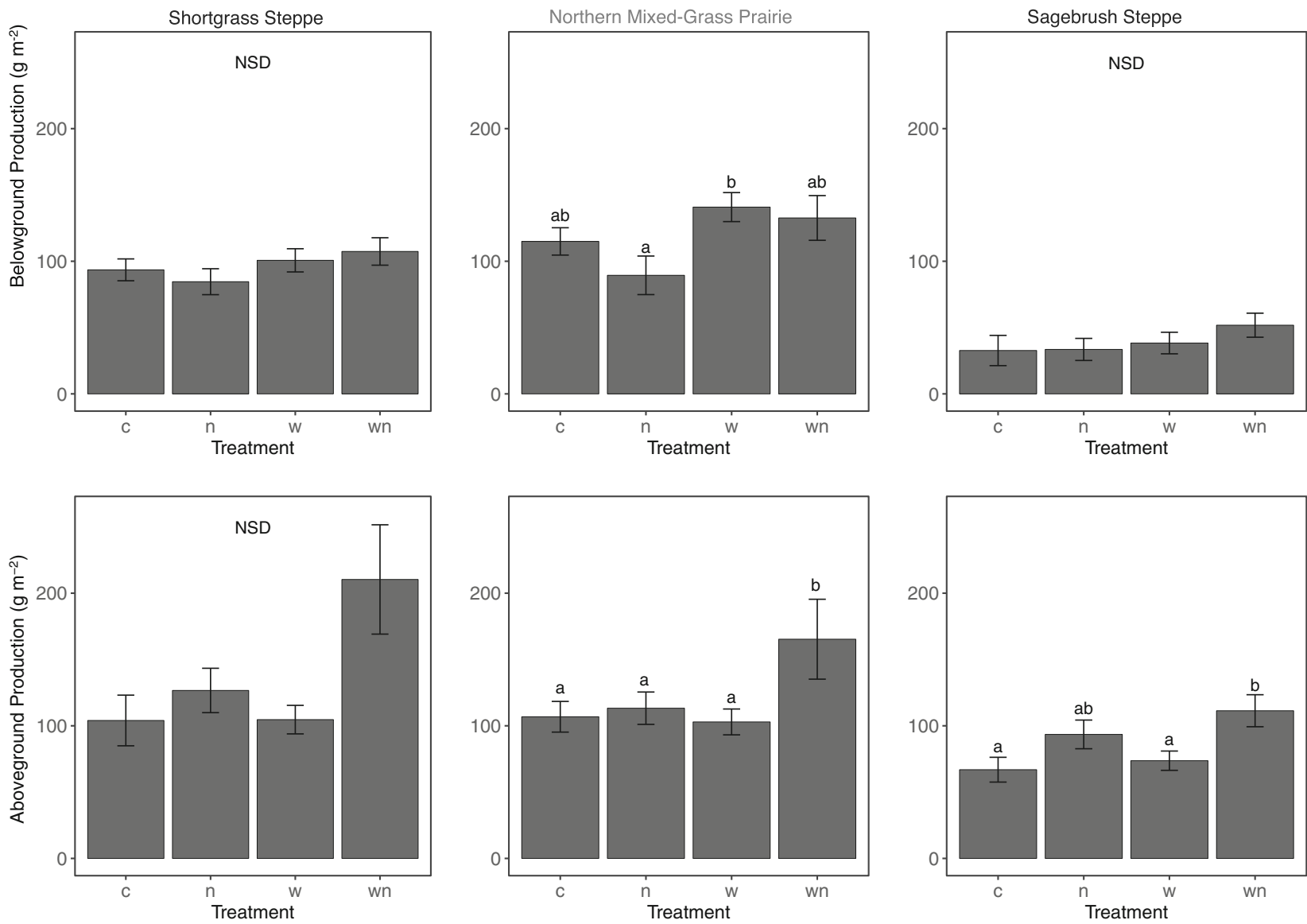

Figure 3. Belowground and aboveground production (non-shrub) after 18 weeks between June 1 and October 5, 2017, by site (shortgrass steppe, northern mixed-grass prairie, and sagebrush steppe) and treatment (control-c; nitrogen-n; water-w; water + nitrogen-wn). The letters (a or b) represent statistically different means $(p<0.05)$ and the bars represent standard error of the mean; NSD connotes no significant differences among treatment means within sites.

(2013) found in a 19-year-old fertilization experiment on grasslands that root biomass increased under the long-term $\mathrm{N}$ fertilization. Experiments in Patagonia (Reyes and Aguiar 2017a, b) found different responses in the two separate works: no root biomass to added $\mathrm{N}$ and large responses that did not appear until after 6 months. Byrne and others (2013) manipulated precipitation from shortgrass steppe and mixed-grass prairie sites both by removing and adding water and found inconsistent responses of root production among years and sites.

Our results do not necessarily clarify the picture for predicting root responses to water and $\mathrm{N}$ in semiarid drylands. Responses to water were consistent but not significant. Mean annual precipitation in 2016-2017 at all sites was greater than the long-term average, and its seasonality varied from the long-term pattern. As a result, the control plots at all of our sites may not have been as water limited as usual, and the effect of water additions were not as large as we had expected, partially explaining why we found no significant differences between the control plots and the water treatment plots (Figure 2). With increased water availability, $\mathrm{N}$ limitation generally increases (Yahdjian and others 2011), but we did not see an indication that water responses were different than water plus $\mathrm{N}$. Previous $\mathrm{N}$ addition studies in grassland ecosystems have found that $\mathrm{N}$ treatment effects may take at least a year to be visible (Lauenroth and others 1978; Jacobsen and others 1996), which could explain we did not see an increase in root production in the $\mathrm{N}$ treatment despite having an unusually high precipitation year. Alternatively, Nalone additions could have resulted in slight decreased allocation to roots, visible though only significant for the mixed-grass prairie, as a result of allometric adjustments (Peng and Yang 2016) to favor aboveground biomass production, as seen in the aboveground biomass results (Figure 3). The addition of water and $\mathrm{N}$ combined increased root production and aboveground production at all 
three sites, but the effect was not significant for root production and was only significant compared to the control for aboveground biomass at the northern mixed-grass prairie and sagebrush steppe sites. Our results indicate that responses to $\mathrm{N}$ in the Great Plains are site- and time-specific, and that when both water and $\mathrm{N}$ availability increase, plants in these ecosystems respond by increasing aboveground production more than belowground production.

The realm of inference of our study is limited by the seasons during which we added water and $\mathrm{N}$, the seasons during which we sampled, and the length of the overall study (one growing season). It is possible that we could have seen different root production responses had we extended our study into the early spring and later fall, and for more years.

\section{Conclusion}

Our study was the first that we know of to examine the seasonal dynamics of root production across a range of dryland ecosystems, and our results suggest that patterns may be explained both by precipitation and plant functional-type dominance. Aboveground responses to addition of water in combination with $\mathrm{N}$ were stronger than belowground responses. Future changes in water availability are more likely to influence belowground production than in $\mathrm{N}$ deposition.

\section{OPEN ACCESS}

This article is distributed under the terms of the Creative Commons Attribution 4.0 International License (http://creativecommons.org/licenses/by/4 $.0 /$ ), which permits unrestricted use, distribution, and reproduction in any medium, provided you give appropriate credit to the original author(s) and the source, provide a link to the Creative Commons license, and indicate if changes were made.

\section{REFERENCES}

Abdel-Magid AH, Schuman GE, Hart RH. 1987. Soil bulk density and water infiltration as affected by grazing systems. J Rangel Manag 40:307-8.

Arguez A, Durre I, Applequist S, Squires M, Vose R, Yin X, Bilotta R. 2010. NOAA's U.S. Climate Normals (1981-2010).

Austin AT, Yahdjian L, Stark JM, Belnap J, Porporato A, Norton U, Ravetta DA, Schaeffer SM. 2004. Water pulses and biogeochemical cycles in arid and semiarid ecosystems. Oecologia $141(2): 221-35$.

Baer SG, Blair JM. 2008. Grassland establishment under varying resource availability: a test of positive and negative feedback. Ecology 89(7):1859-71.
Batjes NH. 1996. Total carbon and nitrogen in the soils of the world. Eur J Soil Sci 47(2):151-63.

Burke IC, Lauenroth WK, Milchunas DG. 1997a. Biogeochemistry of managed grasslands in central North America. In: Paul E, Paustian K, Eds. Organic matter in U.S. agroecosystems. Boca Raton: Lewis Publishers. p 85-102.

Burke IC, Lauenroth WK, Parton WJ. 1997b. Regional and temporal variation in net primary production and nitrogen mineralization in grasslands. Ecology 78(5):1330.

Burke IC, Mosier AR, Hook PB, Milchunas DG, Barrett JE, Vinton MA, McCulley RL, Kaye JP, Gill RA, Epstein HE, and others. 2008. Soil organic matter and nutrient dynamics of the shortgrass steppe ecosystems. In: Lauenroth WK, Burke IC, Eds. Ecology of the shortgrass steppe: a long-term perspective. New York: Oxford University Press. p 522.

Byrne KM, Lauenroth WK, Adler PB. 2013. Contrasting effects of precipitation manipulations on production in two sites within the central grassland region. USA Ecosyst 16(6):103951.

Derner JD, Hess BW, Olson RA, Schuman GE. 2008. Functional group and species response to precipitation in three semi-arid rangeland ecosystems. Arid Land Res Manag 22:81-92.

Epstein HE, Burke IC, Mosier AR. 1998a. Plant effects on spatial and temporal patterns of nitrogen cycling in the shortgrass steppe. Ecosystems 1:374-85.

Epstein HE, Lauenroth WK, Burke IC, Coffin DP. 1997. Productivity patterns of $\mathrm{C} 3$ and $\mathrm{C} 4$ functional types in the US Great Plains. Ecology 78(3):722-31.

Epstein HE, Lauenroth WK, Burke IC, Coffin DP. 1998b. Regional productivities of plant species in the Great Plains of the United States. Plant Ecol 134:23.

Fay PA, Jonathan CD, Knapp AK, Collins SL. 2003. Productivity response to altered rainfall patterns in a C4-dominated grassland. Oecologia 137:245-51.

Fornara DA, Banin L, Crawley MJ. 2013. Multi-nutrient vs. nitrogen-only effects on carbon sequestration in grassland soils. Glob Change Biol 19(12):3848-57.

Gao YZ, Chen Q, Lin S, Giese M, Brueck H. 2011. Resource manipulation effects on net primary production, biomass allocation and rain-use efficiency of two semiarid grassland sites in Inner Mongolia, China. Oecologia 165:855-64.

Gasch CK, Huzurbazar SV, Stahl PD. 2016. Description of vegetation and soil properties in sagebrush steppe following pipeline burial, reclamation, and recovery time. Geoderma 265:19-26. https://doi.org/10.1016/j.geoderma.2015. 11.013 .

Gill RA, Burke IC, Lauenroth WK, Milchunas DG. 2002. Longevity and turnover of roots in the shortgrass steppe: influence of diameter and depth. Plant Ecol 159:241-51.

Gill RA, Jackson RB. 2000. Global patterns of root turnover for terrestrial ecosystems. New Phytol 147(1):13-31.

Harmon ME, Nadelhoffer KJ, Blair JM. 1999. Measuring decomposition, nutrient turnover, and stores in plant litter. In: Robertson GP, Coleman DC, Bledsoe CS, Sollins P, Eds. Standard soil methods for long-term ecological research. New York: Oxford University Press. pp 202-41.

Hayes DC, Seastedt TR. 1987. Root dynamics of tallgrass prairie in wet and dry years. Can J Bot 65:787-91.

Hook P, Lauenroth WK, Burke IC. 1994. Spatial patterns of roots in a semiarid grassland: abundance of canopy openings and regeneration gaps. J Ecol 82(3):485. 
Hook PB, Lauenroth WK. 1994. Root system response of a perennial bunchgrass to neighbourhood-scale soil water heterogeneity. Funct Ecol 8(6):738.

Hooper DU, Johnson L. 1999. Nitrogen limitation in dryland ecosystems: responses to geographical and temporal variation in precipitation. Biogeochemistry 46(1-3):247-93.

Huang J, Yu H, Guan X, Wang G, Guo R. 2016. Accelerated dryland expansion under climate change. Nat Clim Change 6(2):166-71.

Jackson RB, Mooney HA, Schulze ED. 1997. A global budget for fine root biomass, surface area, and nutrient contents. Proc Natl Acad Sci USA 94(14):7362-6.

Jacobsen JS, Lorbeer SH, Houlton HAR, Carlson GR. 1996. Nitrogen fertilization of dryland grasses in the northern Great Plains. J Range Manag 49(4):340.

Korfanta NM, Mobley ML, Burke IC. 2015. Fertilizing western rangelands for ungulate conservation: an assessment of benefits and risks: fertilizing western rangelands. Wildl Soc Bull 39(1):1-8.

Lauenroth WK. 1979. Grassland primary production: North American grasslands in perspective. In: French NR, Ed. Perspectives in grassland ecology. Berlin: Springer. p 3-24.

Lauenroth WK. 2008. Vegetation of the shortgrass steppe. In: Lauenroth WK, Burke IC, Eds. Ecology of the shortgrass steppe: a long-term perspective. New York: Oxford University Press. p 70-83.

Lauenroth WK, Burke IC, Eds. 2008. Ecology of the shortgrass steppe: a long term perspective. Long term ecological research network series. New York: Oxford University Press.

Lauenroth WK, Dodd JL, Sims PL. 1978. The effects of water-and nitrogen-induced stresses on plant community structure in a semiarid grassland. Oecologia 36(2):211-22.

Lauenroth WK, Hunt WD, Swift DM, Singh JS. 1986. Estimating aboveground net primary production in grasslands: a simulation approach. Ecol Model 33(2-4):297-314.

Lauenroth WK, Sala OE. 1992. Long-term forage production of North American shortgrass steppe. Ecol Appl 2(4):397-403.

Lauenroth WK, Whitman WC. 1971. Rapid method for washing roots. J Range Manag 24:308.

Lee CA, Lauenroth WK. 1994. Spatial distributions of grass and shrub root systems in the short grasssteppe. Am Midl Nat $132: 117-23$.

Leetham JW, Milchunas DG. 1985. The composition and distribution of soil microarthropods in the shortgrass steppe in relation to soil water, root biomass, and grazing by cattle. Pedobiologia 28:311-25.

Li J, Lin S, Taube F, Pan Q, Dittert K. 2011. Above and belowground net primary productivity of grassland influenced by supplemental water and nitrogen in Inner Mongolia. Plant Soil 340(1-2):253-64.

Liu L, Greaver TL. 2010. A global perspective on belowground carbon dynamics under nitrogen enrichment: Belowground C dynamics under N enrichment. Ecol Lett 13(7):819-28.

McCulley RL, Burke IC, Nelson JA, Lauenroth WK, Knapp AK, Kelly EF. 2005. Regional patterns in carbon cycling across the Great Plains of North America. Ecosystems 8(1):106-21.

Milchunas DG. 2009. Estimating root production: comparison of 11 methods in shortgrass steppe and review of biases. Ecosystems 12(8):1381-402.

Milchunas DG, Lauenroth WK. 1993. A quantitative assessment of the effects of grazing on vegetation and soils over a global range of environments. Ecol Monogr 63:327-66.
Milchunas DG, Lauenroth WK. 2001. Belowground primary production by carbon isotope decay and long-term root biomass dynamics. Ecosystems 4(2):139-50.

Milchunas DG, Lauenroth WK, Chapman PL, Kazempour MK. 1989. Effects of grazing, topography, and precipitation on the structure of a semiarid grassland. Vegetation 80(1):11-23.

Milchunas DG, Mosier AR, Morgan JA, LeCain DR, King JY, Nelson JA. 2005. Root production and tissue quality in a shortgrass steppe exposed to elevated $\mathrm{CO}_{2}$ : using a new ingrowth method. Plant Soil 268(1):111-22.

Montagnoli A, Terzaghi M, Scippa GS, Chiatante D. 2014. Heterorhizy can lead to underestimation of fine-root production when using mesh-based techniques. Acta Oecol 59:84-90.

Palmquist KA, Schlaepfer DR, Bradford JB, Lauenroth WK. 2016. Spatial and ecological variation in dryland ecohydrological responses to climate change: implications for management. Ecosphere 7(11):e01590.

Peng Y, Guo D, Yang Y. 2017. Global patterns of root dynamics under nitrogen enrichment. Ecol Biogeochem 26(1):102-14.

Peng YF, Yang YH. 2016. Allometric biomass partitioning under nitrogen enrichment: evidence from manipulative experiments around the world. Sci Rep 6:7.

Pennington VE, Bradford JB, Palmquist KA, Renne RR, Lauenroth WK. 2019. Patterns of big sagebrush plant community composition and stand structure in the western US. Rangeland Ecol Manag. https://doi.org/10.1016/j.rama.2018.11.013.

Pielke RA, Doesken NJ. 2008. Climate of the shortgrass steppe. In: Lauenroth WK, Burke IC, Eds. Ecology of the shortgrass steppe. New York: Oxford University Press. p 14-29.

Power JF, Alessi J. 1971. Nitrogen fertilizer of semiarid grasslands: plant growth and soil mineral N levels. Agron J 63:27780.

PRISM Climate Group. 2018. 30 Year Normals 1981-2010. Oregon State University. Available at: http://prism.oregonsta te.edu/.

Reyes MF, Aguiar MR. 2017a. Mind the gap among patches in arid plant communities: rapid root proliferation in response to N addition. J Plant Ecol 12(1):89-95.

Reyes MF, Aguiar MR. 2017b. Root proliferation strategies and exploration of soil patchiness in arid communities. Austral Ecol 42:810-8.

R Core Team. 2018. R: a language and environment for statistical computing [Internet]. Vienna, Austria: R Foundation for Statistical Computing. Available from: https://www.Rproject. org/.

Sala OE, Golluscio RA, Lauenroth WK, Roset PA. 2012. Contrasting nutrient-capture strategies in shrubs and grasses of a Patagonian arid ecosystem. J Arid Environ 82:130-5.

Sala OE, Golluscio RA, Lauenroth WK, Soriano A. 1989. Resource partitioning between shrubs and grasses in the Patagonian steppe. Oecologia 81(4):501-5.

Sala OE, Lauenroth WK. 1985. Root profiles and the ecological effect of light rainshowers in arid and semiarid regions. Am Midl Nat 114(2):406.

Sala OE, Lauenroth WK, Parton WJ. 1992. Long-term soil water dynamics in the shortgrass steppe. Ecology 73(4):1175-81.

Sala OE, Parton WJ, Joyce LA, Lauenroth WK. 1988. Primary production of the central grassland region of the United States. Ecology 69(1):40-5.

Sims PL, Singh JS, Lauenroth WK. 1978. The structure and function of ten western North American grasslands: I. Abiotic and vegetational characteristics. J Ecol 66(1):251. 
Sindhoj E, Hansson A-C, Andren O, Katterer T, Marissink M, Pettersson R. 2000. Root dynamics in a semi-natural grassland in relation to atmospheric carbon dioxide enrichment, soil water and shoot biomass. Plant Soil 223:253-63.

Steinaker DF, Wilson SD, Peltzer DA. 2010. Asynchronicity in root and shoot phenology in grasses and woody plants. Glob Change Biol 16:2241-51.

Stevens CJ, Lind EM, Hautier Y, Harpole WS, Borer ET, Hobbie S, Seabloom EW, Ladwig L, Bakker JD, Chu C et al. 2015. Anthropogenic nitrogen deposition predicts local grassland primary production worldwide. Ecology 96(6):1459-65.

Swindon JG, Lauenroth WK, Schlaepfer DR, Burke IC. 2019. Spatial distribution of roots across three dryland ecosystems and plant functional types. West N Am Nat 79(2):159-69.

USDA, NRCS. 2018. The PLANTS database. Greensboro, NC: National Plant Data Team.

Van Haveren BP, Galbraith AF. 1971. Soil hydrologic and physical properties of the major soil types on pawnee intensive site. Fort Collins Colorado: Watershed Science Department, Colorado State University Grassland Biome Report No.: 11 .
Vogt KA, Vogt DJ, Bloomfield J. 1998. Analysis of some direct and indirect methods for estimating root biomass and production of forests at ecosystem level. Plant Soil 200:71-89.

Walter H. 1971. Natural savannas. In: Burnett JH, Ed. Ecology of tropical and subtropical vegetation. Oliver and Boyd: Edinburgh.

Wedin DA, Tilman D. 1996. Influence of nitrogen loading on species composition and on the carbon balance of grasslands. Science 6(274):1720-3.

White RP, Murray S, Rohweder M, Prince S, Thompson KM. 2000. Grasslands ecosystems. Washington, DC: World Resources Institute.

Yahdjian L, Gherardi L, Sala OE. 2011. Nitrogen limitation in arid-subhumid ecosystems: a meta-analysis of fertilization studies. J Arid Environ 75(8):675-80.

Yahdjian L, Gherardi L, Sala OE. 2014. Grasses have larger response than shrubs to increased nitrogen availability: a fertilization experiment in the Patagonian steppe. J Arid Environ 102:17-20.

Yuan ZY, Chen HYH. 2012. A global analysis of fine root production as affected by soil nitrogen and phosphorus. Proc R Soc B Biol Sci 279:3796-802. 